A. Krasnorutsky, A. Fedorovsky, V. Yashenok

\author{
Ivan Khozedub Kharkiv National Air Force University, Kharkiv
}

\title{
METHOD OF DESCRIPTION FOR THE DYNAMICS OF THE SIGNAL DELAY CHANGE IN DISCRETE TIME WITH CHANGING AIRCRAFT POSITION IN SPACE
}

The article presents an innovative approach to the description of the aircraft range parameter in discrete time when simulating the process of its repositioning in space. A method of describing the dynamics of changes in signal delay in discrete time when the aircraft is changing its spatial position is proposed. Such a model adequately describes the change in signal delay in discrete time. The direction of estimation for the adequacy of radio signal delay change simulation in algorithms of optimum filtration is defined in accordance with the aerodynamic properties of the aircraft. Simulation of the signal delay dynamic change is carried out (it is completely described by the dynamics of change in the distance to the aircraft). The transformation stages of simulation data for the initial model in continuous time with realization of the standard Gaussian random numbers are justified. Information on the simulation data transformation taking into account the correlation matrix of discrete white noise is provided. A method of calculating the transition matrix through the Laplace transform is proposed. The scientific-applied direction of research is determined - it lies in the development of a method for the legitimate representation for the mathematical model of aircraft's changing range in discrete time within one-dimensional space: the longitudinal and the transverse dimensions. This approach takes into account the continuous description for a system of stochastic differential equations. A comprehensive algorithm for modeling the values of discrete white noise on modern computer equipment and calculating the dynamics of the aircraft range parameter changes is proposed. This algorithm allows to correctly form the a priori information about the change of the vector parameters of the aircraft spatial position at discrete moments of time. As a result, it was shown that the use of the obtained information in the optimal filtering algorithms minimizes the error when determining distance to the aircraft and, accordingly, allows to increase the accuracy and adequacy of the signal delay simulation in discrete time. The results of this research can be used in modernization of the existing models and development of promising on-board radar stations, integrated rangefinders, systems of radio technical reconnaissance and electronic warfare systems, as well as in technical implementation of aircraft flight simulation systems.

Keywords: mathematical model, white noise transformations, optimal filtering algorithms, signal delay.

\section{Introduction}

Problem statement. One of the main characteristics in the problems of radar delay filtering is the degree of simulation adequacy for the spatial change of the aircraft position. The task of estimating the adequacy of the radar delay change simulation, in accordance with the aerodynamic properties of the aircraft, lies in the algorithms of optimal filtering.

The model for the dynamics of the radar delay change simulation can be fully described by the change dynamics of the distance to the aircraft, based on the direct dependence [1-3]:

$$
D(t)=\tau(t) \times c,
$$

where $D(t)$ - is the true value of the range parameter between the aircrafts; $\tau(t)$ - is the true value of the signal delay; $c$ - is the speed of light.

The value of the aircraft spatial displacement - the change of the distance to the aircraft that has random characteristics - can be formally described in the following form:

$$
\xi(t)=D(t)+w(t), \quad 0 \leq t \leq T,
$$

where $w(t)$ - are the white Gaussian noise and artificial interference; $[0, T]-$ is the analyzed time interval of the flight.

Analysis of recent researches and publications. In order to obtain values $\hat{D}(t)$, i.e. to estimate the true value of the observation range (2), we can use the apparatus of the optimal filtration theory [1-3]. In this case, the synthesis of efficient filtering algorithms is based on the use of the a priori models for the change dynamics of the filtered parameters.

We can use a known process as a mathematical model of the distance change in a one-dimension space (for example, in the longitudinal or transverse dimension), described in continuous time by the following system of stochastic differential equations:

$$
F(t)=\left\{\begin{array}{l}
\frac{\partial D(t)}{\partial t}=v(t), \\
\frac{\partial v(t)}{\partial t}=-\gamma v(t)+a(t)+\theta(t), \\
\frac{\partial a(t)}{\partial t}=-\alpha a(t)+n_{a}(t),
\end{array}\right.
$$


where $F(t)$ - is the functional dependence for the parameters of the distance to the aircraft at the time $t$, its speed, and acceleration of its movement; $v(t)=d r(t) / d t \quad-$ is the speed of the aircraft; $a(t)=d v(t) / d t-$ is the acceleration of the aircraft's movement; $\theta(t)$ - is the discrete Markov process, which characterizes the parameter change of the distance to the aircraft when performing sharp maneuvers (e.g. combat reversal) and is a sequence of random, rectangular acceleration pulses $a(t) a(t) ; \gamma-$ is a coefficient, which limits variance growth of the parameter $D(t)$ over time; $n_{a}(t)$ - is a "forming" noise with its correlation function $K_{n}(\tau)=N_{a} / 2=2 \alpha \sigma_{a}^{2} \delta(\tau)$. Here, $\sigma_{a}^{2}$ - is the variance of acceleration $a(t), \alpha-$ is a value inverse to the acceleration time constant, $\delta(\tau)-$ is the delta-function.

Formulation of the purpose of the article (problem statement).

The system of equations (3) quite accurately takes into account the smooth change of the range and, accordingly, the signal delay, observed from the steady state. It also sufficiently describes the sharp change in the state of the range parameter of the aircraft [4-6].

However, when working exclusively with digital filtering technology, samples of the input processes are also taken at discrete moments of time [7-9]. Therefore, the scientific and technical task of our main interest is to develop a method of correct representation of the mathematical model of the form (3) in discrete time, i.e. to describe a model of changing the range in a onedimensional space [10-13].

The purpose of the article is to develop a method of describing the change dynamics in the range parameter of the aircraft in discrete time, which will adequately reflect the change dynamics of the signal delay.

\section{Statement of basic materials}

Since the Markov process $\theta(t)$ in (3) is discrete by definition, we will consider the next linear vector stochastic differential equation as a source model in continuous time:

$$
\frac{d \dddot{\lambda}}{d t}=\dddot{A} \dddot{\lambda}(t)+\dddot{n}_{0}(t),
$$

where $\dddot{\lambda}(t)=|D(t), v(t), a(t)|^{T}$ - informative parameter being measured (informative radio signal); $\dddot{A}=\left|\begin{array}{ccc}0 & 1 & 0 \\ 0 & -\gamma & 1 \\ 0 & 0 & -\alpha\end{array}\right|-$ process matrix; $\dddot{n}_{0}(t)-$ is the vector white Gaussian noise with $\left.M\left\{\dddot{n}_{0} t\right)\right\}=0$ and a correlation matrix $\quad M\left\{\dddot{n}_{0}\left(t_{1}\right) \dddot{n}_{0}^{T}\left(t_{2}\right)\right\}=\dddot{Q} \delta\left(t_{2}-t_{1}\right)$, $\dddot{Q}=\frac{N_{a}}{2}\left|\begin{array}{lll}0 & 0 & 0 \\ 0 & 0 & 0 \\ 0 & 0 & 1\end{array}\right|$.

The general solution of equation (4) has the following form:

$$
\lambda(t)=\dddot{F}\left(t-t_{0}\right) \lambda\left(t_{0}\right)+\int_{t_{0}}^{t} F(t-\tau) \dddot{n}_{0}(\tau) d \tau,
$$

where $\dddot{F}(t)$ - is a transition matrix that satisfies the equation:

$$
d \dddot{F}(t) / d t=\dddot{A} \dddot{F}(t),
$$

with the initial condition $\dddot{F}(t)=\dddot{I}$, where $\dddot{I}-$ is a single matrix.

The solution of equation (6) is a matrix exponent determined by a matrix static series:

$$
\dddot{F}(t)=\exp \{\dddot{A} t\}=\dddot{I}+\dddot{A} t+\frac{1}{2} \dddot{A}^{2} t^{2}+\frac{1}{3 !} \dddot{A}^{3} t^{3}+\frac{1}{n !} \dddot{A}^{n} t^{n}
$$

For the discrete moments of time $t_{v+1}$ from (5) taking into account (7), we write:

$$
\dddot{\lambda}_{v+1}=e^{\dddot{A} \Delta \dddot{\lambda}_{v}}+\dddot{n}_{0 v},
$$

where $\quad \dddot{\lambda}_{v+1}=\dddot{\lambda}\left(t_{v+1}\right), \quad \dddot{\lambda}_{v}=\dddot{\lambda}_{(}\left(t_{v}\right), \dddot{n}_{0 v}=\dddot{\vec{n}}_{0 v}\left(t_{v}\right)$, $\Delta=t_{v+1}-t_{v}$

The correlation matrix of discrete white noise takes the next form:

$$
\dddot{D}(\Delta)=M\left\{\dddot{n}_{0 v} \dddot{n}_{0 v}^{T}\right\}=\int_{0}^{\Delta} e^{\ddot{A} \tau} \dddot{Q}^{{ }_{A}} e^{T} \tau \tau .
$$

If we multiply equation (9) on the left by $\dddot{A}$, and apply the matrix analog of retail integration, we get:

$$
\dddot{A} \dddot{D}(\Delta)=d \dddot{D}(\Delta) / d t-\dddot{Q}-\dddot{D}(\Delta) \dddot{A}^{T} \text {. }
$$

This way, the matrix $\dddot{D}(\Delta)$ satisfies the equation:

$$
d \dddot{D}(\Delta) / d t=\dddot{A} \dddot{D}(\Delta)+\dddot{D}(\Delta) \dddot{A}^{T}+\dddot{Q}
$$

with the initial condition $\dddot{D}(0)=0$.

Matrix $\dddot{\mathrm{D}}(\Delta)$, as a symmetric negatively defined matrix, can be represented as:

$$
\dddot{D}=G G^{T},
$$

where $\mathrm{G}-$ is the lower triangular matrix.

Using (12) and (8) we obtain an algorithm for forming values $\dddot{\lambda}_{v+1}$ from $\dddot{\lambda}_{v}$. We also obtain values of the discrete white noise with a single variance: 


$$
\dddot{\lambda}_{v+1}=\dddot{F}(\Delta) \dddot{\lambda}_{v}+G \dddot{n}_{v}
$$

where $M\left\{\dddot{n}_{v} \dddot{n}_{\mu}^{T}\right\}=\dddot{I} \delta_{\mu v}$.

To calculate the transition matrix $\dddot{F}(\Delta)$, we use the Laplace transform [2]. To do that, we shall denote the matrix in the form of $F(p)=L\{\dddot{F}(\Delta)\}$ (each element of which is a Laplace image of the corresponding element of the matrix $\dddot{F}(\Delta)$. This way, from (6) we obtain:

$$
(p \dddot{I}-\dddot{A}) \dddot{F}(p)=\dddot{I} .
$$

Then, if the condition $\operatorname{det}(p \dddot{I}-\dddot{A}) \neq 0$ is met, we get:

$$
\dddot{F}(p)=(p \dddot{I}-\dddot{A})^{-1} \text {. }
$$

Hence,

$$
\vec{\Phi}(\Delta)=L^{-1}\left\{(p \vec{I}-\vec{A})^{-1}\right\} .
$$

By applying this technique to equation (4), we obtain:

$$
\dddot{F}(\Delta)=\left|\begin{array}{ccc}
1 & \frac{1-e^{-\gamma \Delta}}{\gamma} & \frac{1}{\alpha-\gamma}\left[\frac{1}{\gamma}\left(1-e^{-\gamma \Delta}\right)-\frac{1}{\alpha}\left(1-e^{-\alpha \Delta}\right)\right. \\
0 & e^{-\gamma \Delta} & \frac{e^{-\gamma \Delta}-e^{-\alpha \Delta}}{\alpha-\gamma} \\
0 & 0 & e^{-\alpha \Delta}
\end{array}\right|
$$

Given the condition $\Delta<<1$, which is valid for the maneuvering characteristics of the aircraft (aerodynamic properties and the features of its movements), we can use the first approximation for the matrix $\dddot{F}(\Delta)$, which follows from (7), ie:

$$
\vec{\Phi}(\Delta) \approx \vec{I}+\vec{A} \Delta=\left|\begin{array}{ccc}
1 & \Delta & 0 \\
0 & 1-\gamma \Delta & \Delta \\
0 & 0 & 1-\alpha \Delta
\end{array}\right| .
$$

In this case, the approximate value for the matrix $\dddot{D}(\Delta)$ is:

$$
\dddot{D}(\Delta) \approx \Delta \dddot{Q}=\Delta \frac{N_{a}}{2}\left|\begin{array}{lll}
0 & 0 & 0 \\
0 & 0 & 0 \\
0 & 0 & 1
\end{array}\right| .
$$

Finally, taking into account (18) and (19), the mathematical model for the dynamics of changes in the range parameter of the aircraft in discrete time (discrete analogue of the equation system (3)) takes the following form:

$$
\left|\begin{array}{c}
D_{v+1} \\
v_{v+1} \\
a_{v+1}
\end{array}\right|=\left|\begin{array}{ccc}
1 & \Delta & 0 \\
0 & 1-\gamma \Delta & \Delta \\
0 & 0 & 1-\alpha \Delta
\end{array}\right| \cdot\left|\begin{array}{c}
D_{v} \\
v_{v} \\
a_{v}
\end{array}\right|+\sigma_{a} \Delta \sqrt{2 \alpha}\left|\begin{array}{c}
0 \\
0 \\
1
\end{array}\right| n_{v} .
$$

This mathematical model makes it possible to describe in discrete time the dynamics of changes in the parameter of the range of the aircraft, which will adequately reflect the dynamics of changes in signal delay.

\section{Conclusions}

Expression (20) is a comprehensive algorithm for modeling values of $\dddot{\lambda}_{v}$ via modern computer technology. For its practical implementation it is necessary to set the initial value $\dddot{\lambda}_{0}$, and then perform a recurrent calculation of the value $\dddot{\lambda}_{v+1}$ over the known value $\dddot{\lambda}_{v}$. Herewith, the components of the noise vector $n_{v}$ are the implementation of standard Gaussian random numbers.

This way, the application of the developed technique allows to form the a priori information about the change of the vector describing parameters that characterize the position of the aircraft in space, in a mathematically correct way at discrete moments of time. The use of this information in the algorithms of optimal filtering allows to minimize the error of determining the distance to the aircraft and, accordingly, to increase the accuracy and adequacy of the signal delay simulation in discrete time.

This means that, a result, we achieved a significant reduction in the error of range estimation when simulating areas of the aircraft flight, or when designing a complex rangefinder system.

\section{References}

1. Tikhonov, V. and Kharisov, V. (2004), "Statisticheskiy analiz i sintez radiotekhnicheskikh ustroystv $i$ sistem" [Statistical analysis and synthesis of radio engineering devices and systems], Radio and communication, Moscow, $608 \mathrm{p}$.

2. Tikhonov, V. (1986), "Nelineynyye preobrazovaniya sluchaynykh protsessov" [Nonlinear transformations of random processes], Radio and communication, Moscow, $306 \mathrm{p}$.

3. Tikhonov, V. (1977), "Markovskiye protsessy" [Markov processes], Soviet radio, Moscow, 408 p.

4. Kanashenkov, A. and Merkulov, V. (2004), "Otsenivaniye dal'nosti i skorosti v radiolokatsionnykh sistemakh" [Estimation of range and speed in radar systems], Radio engineering, Moscow, $312 \mathrm{p}$.

5. Semenykhyna, D.V., Jukhanov, Ju.V. and Pryvalova, T.Ju. (2015), "Teoreticheskie osnovy radioelektronnoj bor'by. Radioelektronnaya razvedka i radioelektronnoe protivodejstvie" [Theoretical foundations of electronic warfare. Electronic intelligence and electronic countermeasures], JFU, Taganrog, 252 p. 
6. Kozhushko, J. (2011), "Tendenciï rozvitku aviacijnih zasobiv radioelektronnoï borot'bo vijs'kovo-povitryanih sil SSHA" [Trends in the development of aviation means of electronic combat US Air Force], Science and Technology of the Air Forces of Ukraine, No. 2(6), pp. 44-48.

7. Sonin, A.P. (2004), "Oblik perspektivnoj aviacionnoj bortovoj stancii aktivnyh pomekh" [The appearance of a promising aircraft side station active interference], Digital electronic systems, Samara, No. 5, pp. 32-36.

8. Barannik, V., Podlesny, S., Krasnorutskyi, A., Musienko, A. and Himenko, V. (2016), The ensuring the integrity of information streams under the cyberattacks action, 2016 IEEE East-West Design \& Test Symposium (EWDTS), Yerevan, pp. 1-5.

9. Lu, G. (2010), Cancellation of Complicated DRFM Range False Targets via Temporal Pulse Diversity, Progress in Electromagnetics Research C, Vol. 16, pp. 69-84.

10. Barannik, V., Krasnorutskiy, A., Ryabukha, Y. and Okladnoy, D. (2016), Model intelligent processing of aerial photographs with a dedicated key features interpretation, Modern Problems of Radio Engineering, Telecommunications and Computer Science (TCSET), Lviv, pp. 736. https://doi.org/10.1109/TCSET.2016.7452167.

11. Barannik, V.V., Krasnorutskyi, A.A. and Musienko, A.P. (2015), Methodological Base For Transformants Representation in Nonequilibrium Positional Uneven-Diagonal Space, Science-Based Technologies, No. 3(27), pp. 233-238.

12. Barannik, V., Krasnorutskiy, A., Hahanova, A. and Shulgin, S. (2018), Model of syntactic representation of aerofhoto images segmantes, IEEE 14th International Conference "Advanced trends in radioelectronics, telecommunications and computer engineering (TCSET)”, Lviv Polytechnic National University, Lviv, pp. 281-284.

13. Barannik, V., Krasnorutskiy, A. and Hahanova, A. (2013), The positional structural-weight coding of the binary view of transformants, East-West Design \& Test Symposium, pp. 1-4.

\section{Список літератури}

1. Тихонов В. И., Харисов В. Н. Статистический анализ и синтез радиотехнических устройств и систем. Москва : Радио и связь, 2004. 608 с.

2. Тихонов В. И. Нелинейные преобразования случайных процессов. Москва : Радио и связь, 1986. 306 с.

3. Тихонов В. И. Марковские процессы. Москва : Сов. радио, 1977. 408 с.

4. Канащенков А. И., Меркулов В. И. Оценивание дальности и скорости в радиолокационных системах. Москва : Радиотехника, 2004. 312 с.

5. Семенихина Д. В., Юханов Ю. В., Привалова Т. Ю. Теоретические основы радиоэлектронной борьбы. Радиоэлектронная разведка и радиоэлектронное противодействие. Таганрог : Изд-во ЮФУ, 2015. 252 c. ISBN 978-59275-1815-9.

6. Кожушко Я. Н. Тенденції розвитку авіаційних засобів радіоелектронної боротьби військово-повітряних сил США. Наука и техника Повітряних сил Збройних Сил Украӥни. 2011. № 2(6). С. 44-48.

7. Сонин А. П. Облик перспективной авиационной бортовой станции активных помех. Цифровые радиоэлектронные системы. Самара, 2004. № 5. С. 32-36.

8. Barannik V., Podlesny S., Krasnorutskyi A., Musienko A., Himenko, V. The ensuring the integrity of information streams under the cyberattacks action, 2016 IEEE East-West Design \& Test Symposium (EWDTS). Yerevan, 2016. P. 1-5.

9. Lu G. Cancellation of Complicated DRFM Range False Targets via Temporal Pulse Diversity. Progress in Electromagnetics Research C. 2010. Vol. 16. P. 69-84.

10. Barannik V., Krasnorutskiy A., Ryabukha Y., Okladnoy D. Model intelligent processing of aerial photographs with a dedicated key features interpretation, Modern Problems of Radio Engineering, Telecommunications and Computer Science (TCSET). Lviv, 2016. P. 736. https://doi.org/10.1109/TCSET.2016.7452167.

11. Barannik V. V., Krasnorutskyi A. A., Musienko A. P. Methodological Base For Transformants Representation in Nonequilibrium Positional Uneven-Diagonal Space. Science-Based Technologies. 2015. No. 3(27). P. 233-238.

12. Barannik V., Krasnorutskiy A., Hahanova A., Shulgin S. Model of syntactic representation of aerofhoto images segmantes. IEEE 14th International Conference "Advanced trends in radioelectronics, telecommunications and computer engineering (TCSET)”. Lviv : Lviv Polytechnic National University, 2018. P. 281-284.

13. Barannik V., Krasnorutskiy A., Hahanova A. The positional structural-weight coding of the binary view of transformants. East-West Design \& Test Symposium, 2013. P. 1-4.

Received by Editorial Board 07.08.2021

Signed for Printing 14.09.2021

\section{Відомості про авторів:}

\section{Красноруцький Андрій Олександрович}

кандидат технічних наук

викладач Харківського національного університету

Повітряних Сил ім. І. Кожедуба,

Харків, Україна

https://orcid.org/0000-0001-9098-360X

\section{Федоровський Олександр Володимирович}

викладач Харківського національного університету

Повітряних Сил ім. I. Кожедуба,

Миколаїв, Україна

https://orcid.org/0000-0001-5016-8926

\section{Information about the authors:}

\author{
Andrii Krasnorutsky \\ Candidate of Technical Sciences \\ Instructor of Ivan Kozhedub Kharkiv National \\ Air Force University, \\ Kharkiv, Ukraine \\ https://orcid.org/0000-0001-9098-360X
}

\author{
Aleksandr Fedorovskiy \\ Instructor of Ivan Kozhedub Kharkiv National \\ Air Force University, \\ Mykolayiv, Ukraine \\ https://orcid.org/0000-0001-5016-8926
}


Ященок Володимир Жоржевич

кандидат технічних наук

викладач Харківського національного університету

Повітряних Сил ім. І. Кожедуба,

Харків, Україна

https://orcid.org/0000-0002-7806-8078
Volodymyr Yashenok

Candidate of Technical Sciences

Instructor of Ivan Kozhedub Kharkiv National

Air Force University,

Kharkiv, Ukraine

https://orcid.org/0000-0002-7806-8078

\section{МЕТОДИКА ОПИСУ В ДИСКРЕТНОМУ ЧАСІ ДИНАМІКИ ЗМІНИ ЗАТРИМКИ СИГНАЛУ ПРИ ЗМІНІ ПОЛОЖЕННЯ В ПРОСТОРІ ПОВІТРЯНОГО СУДНА}

А.О. Красноруцький, О.В. Федоровський, В.Ж. Ященок

У статті викладений інноваційний підхід опису параметру дальності літального апарату в дискретному часі при моделюванні процесу відтворення зміни його положення в просторі. Запропоновано методику опису в дискретному часі динаміки зміни затримки сигналу при зміні положення в просторі повітряного судна. Така модель адекватно описує зміну затримки сигналу в дискретному часі. Визначено напрямок оиінки адекватності відтворення зміни затримки радіосигналу, враховуючи аеродинамічні властивості повітряного судна, в алгоритмах оптимальної фільтрації. Розкрито моделювання динамічної зміни затримки сигналу, щьо повністю описується динамікою зміни дальності до повітряного судна. Обтрунтовуються етапи перетворення даних моделювання вихідної моделі у безперервному часі з реалізачією стандартних гауссівських випадкових чисел та форми сигналу иляхом перетворення останнього з врахуванням корелячійної матричі дискретного білого шуму. Пропонується метод обчислення перехідної матрииі з використанням перетворення Лапласа. Визначено науково-прикладний напрямок дослідження: розробка методики коректного представлення в дискретному часі математичної моделі зміни дальності літального апарату в одному просторовому виміpi, у поздовжньому або поперечному. Такий підхід враховує опис у безперервному часі системи стохастичних диферениіальних рівнянь. Пропонується вичерпний алгоритм моделювання значень дискретного білого шуму на сучасних засобах обчислювальної техніки при обчисленні динаміки зміни параметру дальності повітряного судна. Надано детальний опис застосування розробленої методики, що дозволяє математично коректно сформувати в дискретні моменти часу апріорні відомості про зміну вектора параметрів, що характеризують положення повітряного судна в просторі. Обтрунтовано, щьо використання отриманої інформачії в алгоритмах оптимальної фільтрації дозволяе мінімізувати погрішність визначення дальності до повітряного судна та відповідно підвищити точність і адекватність відтворення затримки сигналу в дискретному часі. Результати досліджень можуть бути використані при модернізації існуючих зразків та розробиі перспективних бортових радіолокачійних станцій, при проектуванні комплексного вимірювача дальності, комплексів радіотехнічної розвідки та радіоелектронної боротьби, а також в технічній реалізації систем моделювання польоту повітряного судна.

Ключові слова: математична модель, перетворення білого шуму, оптимальні алгоритми фільтрачії, затримка сигналу

\section{МЕТОДИКА ОПИСАНИЯ В ДИСКРЕТНОМ ВРЕМЕНИ ДИНАМИКИ ИЗМЕНЕНИЯ СИГНАЛА ПРИ ИЗМЕНЕНИИ ПОЛОЖЕНИЯ В ПРОСТРАНСТВЕ ВОЗДУШНОГО СУДНА}

\section{А.А. Красноруцкий, А.В. Федоровский, В.Ж. Ященок}

В статье изложен инновационный подход описания параметра дальности летательного аппарата в дискретном времени при моделировании проиесса воспроизведения изменения его положения в пространстве. Предложена методика описания в дискретном времени динамики изменения задержки сигнала при изменении положения в пространстве воздушного судна. Такая модель адекватно описывает изменение задержки сигнала в дискретном времени. Определено направление оиенки адекватности воспроизведения изменения задержки радиосигнала, учитывая аэродинамические свойства воздушного судна, в алгоритмах оптимальной фильтрачии. Раскрыто моделирование динамического изменения задержки сигнала, которое полностью описывается динамикой изменения дальности до воздушного судна. Обосновываются этапы преобразования данных моделирования исходной модели в непрерывном времени с реализацией стандартных гауссовских случайных чисел и формы сигнала путем преобразования последнего с учетом корреляиионной матрицы дискретного белого шума. Предлагается метод вычисления переходной матрицы с использованием преобразования Лапласа. Определено научно-прикладное направление исследования: разработка методики корректного представления в дискретном времени математической модели изменения дальности летательного аппарата в одном пространственном измерении, в продольном или поперечном. Такой подход учитыввает описание в непрерывном времени системы стохастических дифференииальных уравнений. Предлагается исчерпываюший алгоритм моделирования значений дискретного белого шума на современных средствах вычислительной техники при исчислении динамики изменения параметра дальности воздушного судна. Предоставлено детальное описание применения разработанной методи$\kappa и$, что позволяет математически корректно сформировать в дискретные моменты времени априорные сведения об изменении вектора параметров, характеризующих положение воздушного судна в пространстве. Обосновано, что использование полученной информации в алгоритмах оптимальной фильтрачии позволяет минимизировать погрешность определения дальности до воздушного судна и соответственно повысить точность и адекватность воспроизведения задержки сигнала в дискретном времени. Результаты исследований могут быть использованы при модернизаиии существующих образиов и разработке перспективных бортовых радиолокационных станиий, при проектировании комплексного измерителя дальности, комплексов радиотехнической разведки и радиоэлектронной борьбы, а также в технической реализации систем моделирования полета воздушного судна.

Ключевые слова: математическая модель, преобразования белого шума, оптимальные алгоритмы фильтрачии, задержка сигнала. 